\title{
AMBLIOPIA BILATERAL DISERTAI EKSOTROPIA ALTERNANS DAN ASTIGMATISMA MIOPIA KOMPOSITUS
}

\author{
Sigmund I. E. Tumewu \\ Bagian Ilmu Kesehatan Mata Fakultas Kedokteran Universitas Sam Ratulangi \\ Manado \\ Email: sigmundtumewu@yahoo.co.id
}

\begin{abstract}
Amblyopia is a functional disorder of vision without any organic problem, and consists of four types: strabistic, anisometropic, ametropic, and stimulus deprivation. The most common type is strabistic amblyopia. Generally, this disorder occurs in children but their parents do not realize it until their children complain of blurred vision during their activities at school. We reported a male of 12 years old who came to the hospital with a cross-eyed chief complaint. This disorder had been realized by his parents since he was six years old. The eye crossing was permanent, not intermittent, but alternating between his two eyes. Examination performed was visual acuity with a cycloplegic refraction, autorefraction, streak retinoscopy, prism, and cover test for evaluating the eye deviation. Conclusion: Based on all the tests performed, the diagnosis of this patient was bilateral amblyopia accompanied with alternant exotropia and myopic astigmatism. The management of this patient was to correct the refraction disorder with cycloplegic refraction and alternant patching.
\end{abstract}

Keywords: amblyopia, exotropia, astigmatism

\begin{abstract}
Abstrak: Ambliopia adalah suatu kelainan fungsional dari penglihatan tanpa disertai kelainan organik, dan terbagi atas empat tipe yaitu; strabismus, anisometropik, ametropik, dan deprivasi stimulus. Bentuk yang paling sering ditemukan ialah tipe strabismus. Umumnya gangguan ini terjadi pada anak-anak tanpa disadari orang tua dan terdeksi pada saat mengikuti pendidikan di sekolah dengan manifestasi turunnya tajam penglihatan. Kami melaporkan kasus seorang anak laki-laki berusia 12 tahun yang berobat ke Poliklinik Ilmu Kesehatan Mata RSU Prof. Dr. R.D. Kandou Manado dengan keluhan mata juling. Mata juling disadari orang tua sejak pasien berusia enam tahun (kelas $1 \mathrm{SD}$ ). Juling bersifat menetap tidak hilang timbul, tetapi terjadi bergantian mata kiri dan kanan. Pemeriksaan yang dilakukan meliputi pemeriksaan tajam penglihatan (visus) dengan sikloplegik, autorefraksi, streak retinoscopy, pemeriksaan cover test, dan prisma untuk menilai adanya deviasi mata ambliopia. Simpulan: Berdasarkan hasil pemeriksaan yang dilakukan, diagnosis pasien ini ialah ambliopia bilateral disertai eksotropia alternans dan astigmatisma miopia kompositus. Penanganan pasien dilakukan dengan koreksi refraksi sikloplegik dan alternant patching.
\end{abstract}

Kata kunci: ambliopia, eksotropia, astigmatisma

Ambliopia adalah penurunan tajam penglihatan walaupun dengan koreksi refraksi optimal tanpa kelainan pada mata dan jalur penglihatan. ${ }^{1}$ Hal ini disebabkan adanya pengalaman visual yang tidak normal selama proses sensitisasi dalam perkembangan penglihatan pada masa awal kanak-kanak; paling sering disebabkan oleh strabismus, gangguan refraksi, atau keduanya. ${ }^{2}$

Penatalaksanaan ambliopia yaitu dengan memberikan koreksi terhadap gangguan refraksi, diikuti penutupan mata yang baik tajam penglihatannya. ${ }^{3-5}$ Terdapat banyak faktor yang berpengaruh terhadap keberhasilan terapi ambliopia yaitu tajam penglihatan awal, usia dimulai terapi, jenis 
ambliopia, lama terapi, metode terapi, dan kepatuhan terhadap terapi. ${ }^{5,6}$

Eksotropia adalah suatu keadaan didapat atau kongenital (jarang) dimana sumbu visual dari satu atau kedua mata berdeviasi ke luar, yang bersifat konstan, intermiten, atau laten. ${ }^{7}$ Eksotropia alternan merupakan bentuk eksotropia laten dimana bola mata dapat melakukan fiksasi secara bergantian. Hal ini dapat terjadi bila kedua mata masih memiliki tajam penglihatan yang memungkinkan melakukan fiksasi. Terapi eksotropia dapat berupa koreksi terhadap gangguan refraksi yang ada, pemberian kacamata prisma, latihan orthoptik, dan pembedahan. ${ }^{1,4,7}$

Keberhasilan terapi pada ambliopia dan eksotropia dipengaruhi oleh usia dimulainya terapi, terutama bila penanganan dimulai pada anak berusia lebih dari 10 tahun. ${ }^{1}$

\section{LAPORAN KASUS}

Kasus seorang anak laki-laki berusia 12 tahun, datang ke Poliklinik Ilmu Kesehatan Mata dengan keluhan mata juling. Mata juling disadari orang tua sejak pasien berusia enam tahun (SD kelas 1). Juling bersifat menetap, tidak hilang timbul, tetapi terjadi secara bergantian mata kiri dan kanan. Pasien juga merasa mata kabur bila melihat jauh dan mengalami kesulitan untuk melihat tulisan di papan tulis bila duduk di bangku belakang di ruang kelas. Keluhan mata kabur ini dirasakan makin bertambah sejak dua tahun terakhir. Keluhan melihat ganda tidak dijumpai. Riwayat penyakit dahulu, riwayat kejang dan gangguan neurologik tidak ada. Riwayat kehamilan normal, serta tidak terdapat gangguan dan penyakit selama kehamilan. Ayah pasien mengalami gangguan yang sama pada mata kanan, tetapi bersifat hilang timbul.

Pemeriksaan refraksi dilakukan dengan autorefraktometer, retinoskopi dan trial and error menggunakan sikloplegik scopolamin $1 \%$ (Cylon Cendo). Tajam penglihatan mata kanan 6/60 dengan koreksi terbaik S$2,00-0,50120^{\circ} 6 / 20$ dan tajam penglihatan mata kiri 6/60 dengan koreksi terbaik $S$ $-1,50-0,50120^{\circ} 6 / 15$. Pemeriksaan posisi bola mata dengan deviasi Hirscberg $15^{\circ}$ (di tepi pupil), dan dengan Krimsky posisi bola mata netral dengan prisma $30 \Delta$.

Derajat deviasi sama besar untuk penglihatan jauh dan dekat. Pergerakan bola mata kanan dan kiri tidak terbatas pada semua arah. Pemeriksaan versi menunjukan derajat deviasi yang sama ke segala arah. Dengan cross cover test ditemukan alternating exotropia. Pada pemeriksaan dengan Worth's four dot test pasien hanya dapat melihat tiga titik hijau. Pemeriksaan dengan slit lamp dan funduskopi menunjukkan tidak terdapatnya kelainan pada segmen anterior dan segmen posterior bola mata.

Diagnosis yang ditegakkan ialah eksotropia alternans dan astigmatisma miopia kompositus dengan ambliopia bilateral. Terapi yang diberikan pada pasien yaitu kacamata berukuran S $-2,00-0,50 \quad 120^{\circ}$ untuk mata kanan dan S -1,50-0,50 $120^{\circ}$ untuk mata kiri. Saat ini belum dilakukan penutupan pada mata. Pasien diberitahukan untuk kontrol dua minggu setelah pemakaian kacamata.

\section{BAHASAN}

Untuk menegakkan diagnosis ambliopia diperlukan tiga hal, yaitu: 1) penurunan tajam penglihatan meskipun sudah menggunakan koreksi refraksi optimal; 2) penurunan tajam penglihatan ini tidak disebabkan oleh kelainan struktural mata dan jalur visual; dan 3) adanya bukti gangguan stimulasi visual. ${ }^{1}$

Ambliopia lebih sering terjadi unilateral, tetapi dapat juga bilateral. Secara umum dikatakan ambliopia bila penurunan tajam penglihatan terjadi sebesar dua baris atau lebih pada chart pemeriksaan. Penurunan tajam penglihatan pada ambliopia dapat juga sangat kecil, hanya beberapa huruf pada baris 20/20. ${ }^{1,4}$

Pada pasien ini ditemukan tajam penglihatan yang tidak mencapai maksimal dengan koreksi optimal (VAOD 6/15 dan VAOS 6/20) yang jelas menunjukkan ada- 
nya ambliopia. Kelainan refraksi dan adanya strabismus menjadi bukti gangguan stimulasi visual telah terjadi sejak masa partumbuhan (sejak berusia enam tahun menurut alloanamnesis). Hal ini mungkin saja telah terjadi sebelum usia enam tahun, akan tetapi luput dari perhatian orang tua pasien.

Pada pasien ini terdapat beberapa hal yang terjadi bersamaan, yaitu ambliopia (strabismik), eksotropia, dan gangguan refraksi. Diduga adanya gangguan refraksi yang menyebabkan ambliopia (ambliopia refraktif), sedangkan eksotropia merupakan kelainan yang tersendiri.

Bayi atau anak dengan eksotropia yang dapat melakukan fiksasi alternans secara bebas biasanya tidak akan mengalami ambliopia. Secara empiris, ambliopia strabismik lebih sering terjadi pada pasien dengan esodeviasi. ${ }^{1}$ Adanya tajam penglihatan yang hampir sama pada kedua mata menunjukkan bahwa keduanya digunakan untuk melakukan fiksasi sehingga deviasi bukan disebabkan oleh kehilangan stimulus visual. ${ }^{1}$

Eksotropia dapat dikategorikan secara klasik menjadi basic exotropia, pseudodivergence excess, dan true divergence excess. Pasien dengan basic exotropia memiliki konvergensi normal, dan tidak memperlihatkan perbedaan deviasi yang bermakna antara deviasi saat melihat jauh (distance deviation) dan melihat dekat (near deviation); bila ada, biasanya $<10 \Delta .^{8}$

Deviasi mata pada pasien ini telah diamati sejak masih kecil. Hasil pemeriksaan menunjukkan deviasi sama besar untuk fiksasi jauh dan dekat dan deviasi menetap, tidak hilang timbul, yang muncul sejak usia dini. Hal ini menunjukkan adanya suatu basic exotropia. Adanya riwayat ayah yang juga mengalami eksotropia mengarahkan ke kecurigaan penyebab eksotropia genetik.

Penurunan tajam penglihatan mungkin diakibatkan oleh gangguan refraksi selama masa perkembangan penglihatan pada usia kurang dari enam tahun. Miopia <6 D jarang menyebabkan ambliopia karena keadaan ini masih memungkinkan pasien untuk melihat dekat. ${ }^{1}$

Hubungan eksotropia dan miopia telah ditunjukkan dalam berbagai penelitian. Mohney et al. mengikuti perkembangan 135 pasien eksotropia selama periode 20 tahun dan menemukan bahwa $>90 \%$ dari anak-anak menjadi rabun jauh pada saat mereka mencapai usia 20-an. Adanya kebutuhan konvergensi akomodasi yang berlebihan dicurigai sebagai faktor penyebab. ${ }^{9}$

Penanganan pada pasien ini harus meliputi koreksi kelainan refraksi, ambliopia, dan perbaikan posisi bola mata bila memungkinkan. Kacamata diberikan dengan koreksi penuh yang sesuai dengan hasil refraksi sikloplegik yaitu $S-2,00-0,50$ $120^{\circ}$ untuk mata kanan dan $\mathrm{S}-1,50-0,50$ $120^{\circ}$ untuk mata kiri. Beberapa sumber menyarankan pemberian overkoreksi $-0,50$ D pada eksotropia untuk merangsang konvergensi pada akomodasi, tetapi pendapat ahli lain tidak menyarankannya karena akan menyebabkan astenopia dan mengurangi kepatuhan memakai kacamata. ${ }^{1}$

The American Academy of Ophthalmology dalam Preferred Practice Pattern memberikan panduan pemberian kacamata miopia pada anak tanpa strabismus bila kelainan $\geq-4$ D pada anak berusia $0-2$ tahun, dan >-3D pada anak berusia 2-3 tahun. Pada anak dengan strabismus, kacamata diberikan bila miopia $\geq-1,25$ D pada esotropia, dan >-1D pada eksotropia. ${ }^{1}$

Langkah pertama terapi pada pasien ambliopia ialah memberikan gambaran yang jernih pada retina. Koreksi kelainan refraksi harus dilakukan seoptimal mungkin. Pada pasien ambliopia dengan kelainan refraksi, pemberian kacamata saja dapat memperbaiki tajam penglihatan dalam waktu kurang lebih enam bulan, tanpa oklusi.

Langkah kedua setelah koreksi refraksi ialah menghilangkan dominasi satu mata dengan oklusi. Bila tidak terdapat perbaikan tajam penglihatan dengan koreksi kacamata, dapat dilakukan terapi oklusi., ${ }^{1,3}$ Terapi oklusi pada ambliopia bilateral dapat diberikan secara bergantian pada kedua mata. Oklusi patching belum diberikan pada pasien ini. Terapi oklusi 
pada pasien ini direncanakan setelah pemakaian kacamata lebih dari satu bulan agar dapat menilai hasil kemajuan tajam penglihatan.

Terapi oklusi yang direncanakan ialah oklusi paruh waktu. Oklusi dilakukan dengan paruh waktu 2-6 jam setiap mata secara bergantian. Oklusi penuh (full time) dan oklusi paruh waktu menunjukkan hasil yang sama baiknya, tetapi dengan risiko induksi ambliopia pada mata sehat yang lebih kecil pada oklusi paruh waktu. ${ }^{1}$ Laporan penelitian tahun 2000 menunjukkan hasil yang sama baik pada oklusi satu jam perhari diikuti aktivitas dekat (near activity) yang intensif.

Keberhasilan penanganan ambliopia dipengaruhi banyak faktor, antara lain tajam penglihatan awal, usia dimulai terapi, jenis ambliopia, lama terapi, metode terapi, dan kepatuhan terhadap terapi. Mengenai usia saat dimulai terapi ambliopia masih kontoversial. Terapi yang efektif seharusnya dimulai pada usia dimana sistem penglihatan masih imatur dan masih berkembang, yaitu pada dekade pertama kehidupan. Umumnya, semakin muda usia dimulai terapi, semakin tinggi keberhasilan terapi.

The American Academy of Ophthalmology dalam Preferred Practice Pattern for amblyopia merekomendasikan bahwa terapi harus dipertimbangkan sampai anak berusia 10 tahun. ${ }^{1}$ Park et al. mengemukakan keberhasilan terapi ambliopia yang dimulai pada anak berusia $>9$ tahun, ${ }^{2}$ sedangkan Pediatric Eye Disease Investigator Group menunjukkan keberhasilan terapi sampai usia 17 tahun. ${ }^{6}$

Penanganan eksotropia dilakukan dengan memberikan koreksi tajam penglihatan terbaik disertai latihan konvergensi. Latihan konvergensi orthoptik (pencil push up) dilakukan dengan melihat objek dekat (pensil) pada jarak dekat tetapi masih bisa terjadi fusi, kemudian objek digerakkan perlahan-lahan sampai fusi tersebut hilang (diplopia). Latihan ini dinyatakan berhasil bila pasien dapat mengenali diplopia.

\section{SIMPULAN}

Pada pasien ini terjadinya ambliopia disebabkan oleh gangguan refraksi (ambliopia refraktif). Pemberian kacamata untuk koreksi kelainan refraksi diharapkan dapat memperbaiki tajam penglihatan. Perbaikan tajam penglihatan dan latihan orthoptik diharapkan dapat memperbaiki eksotropia.

\section{DAFTAR PUSTAKA}

1. Wu CS, Fulton A. Amblyopia. In: Albert DM, Miller JW, Azar DT, Blodi BA, editors. Albert and Jakobiec's Principles and Practice of Ophthalmology (Third Edition). Philadelphia: Elsevier (WB Saunders), 2008; Chapter 300. p.251-89.

2. Park KH, Hwang JM, Ahn JK. Efficacy of amblyopia therapy initiated after 9 years of age. Eye. 2004;18:571-4.

3. American Academy of Ophthalmology. Basic and Clinical Science Course. Exodeviation. In: Pediatric Ophthalmology and Strabismus, Section 6. San Francisco: The Foundation of American Academy of Ophthalmology, 2011; p.101-3.

4. Wright WK. Exodeviation. In: Wright WK, Spiegel PH, Thompson L, editors. Handbook of Pediatric Strabismus and Amblyopia. Chicago: Springer, 2006; p.266-82.

5. Trattler WB, Kaisser PK, Friedman NJ. Pediatrics/strabismus. Review of Ophthalmology (Second Edition). Shanghai: Saunders Elvesier, 2012; p. 224-30.

6. Pediatric Eye Disease Investigator Group. Randomized trial of treatment of amblyopia in children aged 7 to 17 years. Arch Ophthalmol. 2005;123:43747.

7. Diamond GR. Exotropia. In: Yanoff M, Duker JS, editors. Ophthalmology (Second Edition). Philadelphia: Mosby Elvesier, 2004. p.117-24.

8. Wright KW. Visual development and amblyopia. In: Wright KW, Spiegel $\mathrm{PH}$, editors. Paedriatic Ophthalmology and Strabismus (Second Edition). New York: Springer, 2003. p. 157-71.

9. Ekdawi SN, Nusz KJ, Diehl NN, Mohney DG. The development of myopia among children with intermittent exotropia. Am J Ophthalmol. 2010;149: 503-7. 